\title{
ARSENIC CONTENTS AND SPECIATION AT DIFFERENT GROWTH STAGES OF SARGASSUM FUSIFORME [HARV.] SETCHELL (HIJIKI), AN EDIBLE SEAWEED
}

\author{
HUANG, S. X. ${ }^{1,2}-$ JIANG, Q. ${ }^{2}-$ DING, Y. F. ${ }^{2}-$ WANG, F. J. ${ }^{2}-$ ZHU, C. ${ }^{1,2^{*}}$ \\ ${ }^{1}$ College of Life Sciences, Zhejiang University, Hangzhou 310058, China \\ ${ }^{2}$ Key Laboratory of Marine Food Quality and Hazard Controlling Technology of Zhejiang \\ Province, China Jiliang University, Hangzhou 310018, China \\ *Corresponding author \\ e-mail:pzhch@cjlu.edu.cn
}

(Received $19^{\text {th }}$ Nov 2019; accepted $10^{\text {th }}$ Feb 2020)

\begin{abstract}
Sargassum fusiforme (hijiki) is a popular edible seaweed in some Asian countries. However, it has been shown to have high concentrations of arsenic, mainly the more toxic inorganic arsenic. In this study, we determined the concentration, species, distribution, and absorption kinetics of arsenic (As), and the influence of different exogenous substances on its absorption. Arsenic content in the mature stage of hijiki reached up to $84.37 \mathrm{mg} / \mathrm{kg}$ dry weight. Inorganic arsenic (iAs) accounted for $68 \%$ of the total arsenic, while Arsenate (As (V)) accounted for more than 50\% of total inorganic arsenic. The contents of arsenic in different hijiki organs decreased in the following order rhizoid $>$ stem $>$ leaf $>$ airbag. Subcellular distribution of arsenic in untreated hijiki decreased in the order: cell walls > cell organelles > cytoplasm. In hijiki, arsenate had a higher absorption rate than arsenite (As (III)), with $\mathrm{V}_{\max }$ and $\mathrm{k}_{\mathrm{m}}$ about 2 times and 3 times those of As (III), respectively. The absorption of As (V) was inhibited by phosphorus, but was not affected by glycerol. The opposite was true in the case of As (III) adsorption. Sodium vanadate significantly increased the efflux of As (V), but had no effect on As (III). Carbonylcyanide-pchlorophenyl hydrazone (CCCP) and glycerol inhibited the arsenite efflux, but had no influence on arsenate.
\end{abstract}

Keywords: arsenic speciation, arsenic distribution, arsenic absorption, influx, efflux

\section{Introduction}

Arsenic is a semi-metal or metalloid which is widely distributed in the environment and it is present in both terrestrial and aquatic systems (Wang et al., 2019). It is a known human carcinogen (Rosen, 2002; García Salgado et al., 2008; Carey et al., 2012). The Agency for Toxic Substances and Disease Registry (ATSDR) ranked arsenic at the top of the substance priority list (ATSDR, 2018). The toxicity of arsenic is especially associated with liver, bladder, lung, and skin cancer (Rose et al., 2007). This element occurs in various chemical forms with different toxicological characteristics in the environment and organisms (Kohlmeyer et al., 2003; Panuccio et al., 2012). Arsenic speciation in the environment is complex and includes both inorganic and organic forms. Inorganic arsenic comprises of arsenate and arsenite. Organic arsenicals include monomethylarsonic acid (MMA), dimethylarsinic acid (DMA), trimethylarsine (TMA), tetramethylarsonium ion (TMA), arsenobetaine (AsBet), arsenocholine (AsCho), and arsenosugars (Kohlmeyer et al., 2003; Quaghebeur et al., 2005). Moreover, inter-conversions between species regulated by both biotic and abiotic processes have been reported (Carey et al., 2012).

Generally speaking, inorganic arsenicals are more toxic than their organic counterparts (Nogueira et al., 2018), and arsenite is much more toxic, soluble, and 
mobile than arsenate (Quaghebeur et al., 2005; Raab et al., 2007; Yang et al., 2016). Organic arsenicals such as DMA and MMA usually have lower toxicities. Therefore, determination of arsenic speciation is essential for understanding and evaluating the safety of edible organisms which accumulate arsenic.

Marine algae are usually thought of as "health food" and consumed directly as such. This is because of the nutritional and therapeutic benefits that they provide. Sargassum fusiforme (hijiki), a brown edible algae (Phaeophyta, Sargassum), is traditionally consumed by the Japanese as one of seaweed foodstuffs due to its richness in essential minerals, and dietary fibre content. The total fiber in hijiki was much higher compared with other seaweeds, such as Laminaria japonica, Porphyra tenera, which showed more benefits to human health especially to intestines. (Zheng et al., 2013) However, marine algae have a greater ability to accumulate arsenic and usually have higher arsenic contents than terrestrial organisms (Hanaoka et al., 2006). In terrestrial organisms, the arsenic content rarely exceeds $1 \mu \mathrm{g} / \mathrm{g}$ (dry weight), while it ranges from 1 to $100 \mu \mathrm{g} / \mathrm{g}$ in marine organisms (Ichikawa et al., 2006).

The concentration of arsenic varies in different organisms, as well as its species. In rice, the predominant inorganic arsenic is arsenite, whereas in marine algae, inorganic arsenic is present mostly as arsenate (Kohlmeyer et al., 2003). It has been reported that the arsenic species in marine organisms are usually organic arsenicals such as arsenobetaine and arsenosugars which are forms considered less toxic than the inorganic forms of arsenic (Ichikawa et al., 2010). However, there are exceptions. In hijiki, the concentration of iAs is up to $135 \mathrm{mg} / \mathrm{kg}$ of dry weight, while the content of inorganic arsenic may range from 50 to $80 \%$ of its total arsenic content (Almela et al., 2005; Yokoi et al., 2012). Thus, the high contents of inorganic arsenic in hijiki have raised serious toxicological concerns among consumers in the past decades (Wondimu et al., 2007). Indeed, the Food Inspection Agency of Canada (2001), the UK Food Standards Agency (2004), and similar institutions in other countries, have warned consumers not to eat hijiki (Wondimu et al., 2007; Yokoi et al., 2012).

In this study, we determined the concentration, species, distribution, and absorption kinetics of arsenic, and the influence of different exogenous substances on its absorption.

\section{Materials and Methods}

\section{Sample preparation}

The research was carried out in the year of 2016. The samples used in this research were cultivated, in Dongtou breeding base of Zhejiang Mariculture Research Institute (Dongtou County, Zhejiang Province, China), under natural conditions. In order to track the changes of arsenic content in hijiki, we took samples at monthly interval from January to May, that was cover the growth period of hijiki from seedling to maturity. There were two varieties of hijiki were sampled. Fresh weight of the native species ( $250 \mathrm{~g}$ of whole plant) was sampled monthly, whereas $250 \mathrm{~g}$ of each Korean sample (whole plant) was collected from January to March. Three separate samples were collected each time. The samples were washed in seawater, kept in plastic bags, and immediately transported to the laboratory. All samples were then washed with tap water, followed by washing three times in ultra-pure water. Thereafter, each sample was freeze-dried to a constant mass and ground to homogenous powder before use. For the 
study of arsenic distribution, different organs (stem, leaf, air sac and rhizoid) were separated before freeze-drying, and then ground to homogenous powder.

\section{Determination of total arsenic in hijiki (S. fusiforme) and different hijiki organs}

Milled sample of hijiki $(0.2 \mathrm{~g})$ was added to $6 \mathrm{ml}$ concentrated nitric acid. The mixture was left for $12 \mathrm{~h}$, and then digested in a MARS 5 microwave oven. Each sample was digested in triplicate. The following conditions were used in the microwave digestion which was modified by Han et al. (2009): the temperature was increased to $120^{\circ} \mathrm{C}$ in $5 \mathrm{~min}$, held for $5 \mathrm{~min}$, then increased to $160^{\circ} \mathrm{C}$ in $5 \mathrm{~min}$, kept constant for $20 \mathrm{~min}$, and finally increased to $180^{\circ} \mathrm{C}$ for $20 \mathrm{~min}$. After dilution and filtering, the digest was brought to a final volume of $25 \mathrm{ml}$ with ultra-pure water. Then, total arsenic was measured using hydride generation-flame atomic absorption spectrometry (HVGFAAS).

\section{Determination of inorganic arsenic}

The inorganic arsenic was extracted in accordance with the procedure of National Standards of China (National Food Safety standard, 2003).

Hijiki powder $(1.00 \mathrm{~g})$ was weighed into a $25 \mathrm{ml}$ test tube, and $20 \mathrm{ml}$ of $50 \%(\mathrm{v} / \mathrm{v})$ hydrochloric acid was added. The mixture was kept in a water bath at $60^{\circ} \mathrm{C}$ for $18 \mathrm{~h}$, during which time it was shaken several times in order to complete the extraction. On cooling to room temperature, the solution was filtered, and $1 \mathrm{ml}$ potassium iodide $(10 \%$ $\mathrm{m} / \mathrm{v})$ - thiocarbamide $(5 \% \mathrm{~m} / \mathrm{v})$ was added to $4 \mathrm{ml}$ of the filtrate. The volume of the solution was made up to $10 \mathrm{ml}$ with ultra-pure water. Inorganic arsenic was determined using HVG-FAAS.

\section{Determination of arsenic speciation}

Arsenic speciation was determined using the method referred to in the manufacturer's manual of the SA-10 Atomic Fluorescence Speciation Analyzer. Each hijiki sample was weighed $(0.5 \mathrm{~g})$ and put in a test tube, $4 \mathrm{ml}$ of $10 \%(\mathrm{v} / \mathrm{v}) \mathrm{HCl}$ was added. Then, the sample was spun at $100 \mathrm{rpm}$ in a water bath at $70^{\circ} \mathrm{C}$ for $1 \mathrm{~h}$, and $4 \mathrm{ml}$ of ultra-pure water was added. The mixture was warmed in a water bath at $70^{\circ} \mathrm{C}$ for $1 \mathrm{~h}$, and centrifuged at $3000 \mathrm{rpm}$ for $15 \mathrm{~min}$. The supernatant $(2 \mathrm{ml})$ was mixed with $2 \mathrm{ml}$ $20 \%(\mathrm{v} / \mathrm{v})$ hydrogen peroxide and put into a water bath at $70^{\circ} \mathrm{C}$ for $20 \mathrm{~min}$. Thereafter, the mixture was filtered through a $0.45 \mu \mathrm{m}$ filter membrane before injection into a chromatographic column. The speciation was analysed using SA-10 Atomic Fluorescence Speciation Analyzer (SA-10 AFSA). Triplicate analyses were performed for each sample.

\section{Subcellular distribution of arsenic in hijiki}

Fresh sample $(0.5 \mathrm{~g})$ and samples treated with $5 \mu \mathrm{mol} / \mathrm{L}$ and $50 \mu \mathrm{mol} / \mathrm{L}$ A sodium arsenate (As) for $24 \mathrm{~h}$ were used for subcellular distribution experiments. The samples were homogenized with precooled homogenate, and all homogenization and separation processes were carried out on ice. The total volume of homogenate and tissue was controlled at about $20 \mathrm{ml}$. The homogenate was transferred into a 50-ml centrifuge tube, and ultrasonic cell breaker was used for ultrasonic crushing. Thereafter, it was centrifuged in a high-speed freezing centrifuge for $30 \mathrm{sec}$ at $300 \mathrm{~g}$, and the precipitate (cell wall component) was collected. The supernatant was centrifuged in a high-speed 
freezing centrifuge for $45 \mathrm{~min}$ at $20000 \mathrm{~g}$. The bottom debris contained the cytosolic organelles, while the supernatant was the cytosolic portion containing macromolecular organic matter and inorganic ions in the cytoplasm and vacuole. Each of the portions from centrifugation was subjected to microwave digestion, and the content of arsenic was determined as described earlier.

\section{Kinetics of arsenic uptake by hijiki}

Fresh hijiki samples were cleaned with ultra-pure water and dried with absorbent paper. About 15-g samples of hijiki were weighed and put in $0.5 \mathrm{~L}$ artificial seawater with different concentrations of arsenate or arsenite $(0,10,20,40,60$ and $80 \mu \mathrm{mol} / \mathrm{L})$, each of which was repeated 3 times. After 30 min of treatment, all samples were soaked in phosphate buffer solution $\left(1 \mathrm{mmol} / \mathrm{L} \mathrm{K}_{2} \mathrm{HPO}_{4}, 5 \mathrm{mmol} / \mathrm{L} \mathrm{MES,} 0.5 \mathrm{mmol} / \mathrm{L} \mathrm{CaCl}_{2}\right.$, $\mathrm{pH}$ 6.0) for $10 \mathrm{~min}$ to wash off the As on the surface (Xu et al., 2007). Then, samples were washed with ultra-pure water, and the surface water was removed with absorbent paper, followed by drying. Finally, the arsenic content was determined as described earlier.

\section{Arsenic influx and efflux in hijiki}

This experiment was used to determine if arsenate and arsenite are taken up via the $\mathrm{P}$ and aquaporin transporters, respectively. The effect of $\mathrm{P}\left(\mathrm{K}_{2} \mathrm{HPO}_{4} \cdot 3 \mathrm{H}_{2} \mathrm{O}\right)$ and glycerol on arsenic influx were investigated. Shoots of the plant (about $15 \mathrm{~g}$ ) were subjected to three treatments: control $(50 \mu \mathrm{mol} / \mathrm{L}$ sodium arsenate As $(\mathrm{V})$ or sodium arsenite As (III) solution $+100 \mu \mathrm{mol} / \mathrm{L} \mathrm{P}\left(\mathrm{K}_{2} \mathrm{HPO}_{4} \cdot 3 \mathrm{H}_{2} \mathrm{O}\right)$ or $+20 \mathrm{mmol} / \mathrm{L}$ glycerol. After treating for $1 \mathrm{~h}$, the samples were immersed in $1 \mathrm{mmol} / \mathrm{L} \mathrm{K}_{2} \mathrm{HPO}_{4}$ solution containing $5 \mathrm{mmol} / \mathrm{L}$ MES and $0.5 \mathrm{mmol} / \mathrm{L} \mathrm{CaCl} 2, \mathrm{pH} 6.0$, in ice bath for $10 \mathrm{~min}$ to wash off the surface As (Xue et al., 2012). Then, the samples were washed and dried to constant weight, and ground into powder. The arsenic content was determined after microwave digestion.

The metabolic inhibitor carbonyl cyanide m-chlorophenylhydrazone (CCCP), P-type ATPase inhibitor sodium vanadate, and glycerol were used to investigate whether the efflux of As by hijiki followed the same transport pathway as its influx. The samples of hijiki treated with $50 \mu \mathrm{mol} / \mathrm{L}$ arsenate As (V) or arsenite As (III) for $24 \mathrm{~h}$ were soaked in $1 \mathrm{mmol} / \mathrm{L} \mathrm{K}_{2} \mathrm{HPO}_{4}$ solution containing $5 \mathrm{mmol} / \mathrm{L} \mathrm{MES} \mathrm{and} 0.5 \mathrm{mmol} / \mathrm{L} \mathrm{CaCl}_{2}$, $\mathrm{pH}$ 6.0, in ice bath for $10 \mathrm{~min}$ (Xue et al., 2012). Then the samples were cleaned and divided into 4 groups, and exposed to fresh artificial seawater with different treatments: control (artificial seawater), $1 \mu \mathrm{mol} / \mathrm{L} \mathrm{CCCP}, 200 \mu \mathrm{mol} / \mathrm{L}$ sodium vanadate, or $10 \mathrm{mmol} / \mathrm{L}$ glycerol. After 2 hours of treatment, $25 \mathrm{ml}$ water samples were taken from each group, and the arsenic content was determined after filtration with $0.45 \mu \mathrm{mol} / \mathrm{L}$ microporous membrane.

Triplicate analyses were performed for each sample. The final results were expressed in mean $\pm \mathrm{SD}$.

\section{Results}

\section{Total and inorganic arsenic contents}

The total and inorganic arsenic contents at different growth stages of the two hijiki varieties (Chinese and Korean) are shown in Table 1. The total arsenic concentration varied from 35.05 to $84.37 \mathrm{mg} / \mathrm{kg}$ (dry weight) at different growth stages from January 
to May. With growth of the seaweed, the total arsenic concentration increased. The variation in the levels of inorganic arsenic was in accord with that of total arsenic concentration, varying from 24.21 to $58.00 \mathrm{mg} / \mathrm{kg}$ dry weight. Thus, the arsenic concentration in the two hijiki varieties increased with growth.

Table 1. Arsenic contents at different stages of growth of two Sargassum fusiforme varieties

\begin{tabular}{c|c|c|c|c|c|c}
\hline \multirow{2}{*}{$\begin{array}{c}\text { Stage of } \\
\text { growth }\end{array}$} & \multicolumn{3}{|c|}{ Native variety } & \multicolumn{3}{c}{ Korean variety } \\
\cline { 2 - 7 } & t-As & i-As & \% i- As & t-As & i-As & $\%$ i- As \\
\hline Jan & $48.72 \pm 7.98 \mathrm{a}$ & $40.29 \pm 4.27 \mathrm{f}$ & $82.69 \%$ & $35.05 \pm 2.56 \mathrm{~d}$ & $24.21 \pm 1.89 \mathrm{~h}$ & $69.07 \%$ \\
Feb & $56.98 \pm 7.97 \mathrm{a}$ & $49.18 \pm 11.21 \mathrm{fg}$ & $86.31 \%$ & $38.31 \pm 4.72 \mathrm{~d}$ & $37.99 \pm 2.80 \mathrm{fgi}$ & $99.16 \%$ \\
Mar & $68.54 \pm 6.48 \mathrm{~b}$ & $51.30 \pm 4.55 \mathrm{~g}$ & $74.85 \%$ & $56.97 \pm 3.67 \mathrm{ae}$ & $45.44 \pm 1.14 \mathrm{gj}$ & $79.76 \%$ \\
Apr & $72.29 \pm 4.17 \mathrm{~b}$ & $54.08 \pm 2.21 \mathrm{~g}$ & $74.81 \%$ & $\mathrm{ND}$ & $\mathrm{ND}$ & $\mathrm{ND}$ \\
May & $84.37 \pm 8.27 \mathrm{c}$ & $58.00 \pm 0.91 \mathrm{~g}$ & $68.74 \%$ & $\mathrm{ND}$ & $\mathrm{ND}$ & $\mathrm{ND}$ \\
\hline
\end{tabular}

t-As: total arsenic. i-As: inorganic arsenic. percentage of i- As: percentage of inorganic arsenic. ND: not determined. Data are expressed in $\mathrm{mg} / \mathrm{kg}$ dry weight, and are mean of triplicate assays. The final results were expressed in mean \pm SD

The percentage of inorganic arsenic varied from 68.74 to $86.31 \%$ in the native variety. In general, in native hijiki, the percentage of inorganic arsenic decreased with growth. This trend was close to those reported previously i.e. 69 to $72 \%$ (Rose et al., 2007).

\section{Arsenic contents in different hijiki organs}

The arsenic contents of different hijiki organs showed a lot of variation. The arsenic levels in the rhizoid, leaf, air sac and stem were 31.92, 27.23, 20.66 and $14.66 \mathrm{mg} / \mathrm{kg}$ dry weight, respectively. These results are shown in Figure 1.

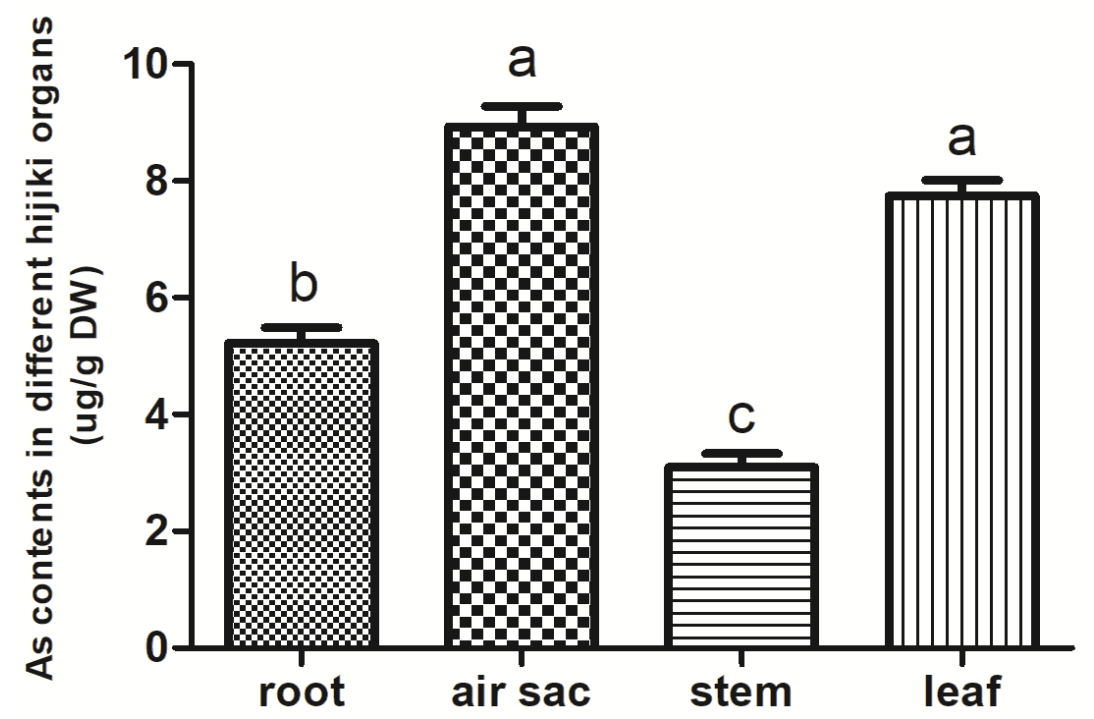

Figure 1. Arsenic contents in different organs of Sargassum fusiforme 


\section{Subcellular distribution of arsenic in hijiki}

The subcellular distribution of arsenic in hijiki is shown in Figure 2. The results showed that the subcellular distribution and compartmentalization of arsenic in hijiki differed greatly. In the untreated hijiki, the content of arsenic decreased in the order: cell wall > organelle > cell fluid, accounting for 48, 33 and 19\% of total arsenic, respectively. However, the arsenic content in each component of hijiki increased after 5 and $50 \mu \mathrm{mol} / \mathrm{L}$ arsenic treatment. After $5 \mu \mathrm{mol} / \mathrm{L}$ sodium arsenate treatment, the order of arsenic content was: cell wall > cell fluid > organelle, accounting for 53, 24 and 23\% of the total, respectively. After $50 \mu \mathrm{mol} / \mathrm{L}$ As treatment, the content of arsenic in each part was in the order of cell wall > cell fluid > organelle, accounting for 51, 11 and 38\% of the total, respectively. The content of arsenic varied in the order of cell wall $>$ cell fluid $>$ organelle after treatment with $5 \mu \mathrm{mol} / \mathrm{L}$ As and $50 \mu \mathrm{mol} / \mathrm{L}$ As, with highest proportion of arsenic in cell wall. Moreover, the increment in arsenic level in cell wall was the largest after $5 \mu \mathrm{mol} / \mathrm{L}$ As treatment, but the increment of arsenic in cell fluid was the largest after $50 \mu \mathrm{mol} / \mathrm{L}$ As treatment. Thus, the increase in arsenic was mainly concentrated in the cell wall of hijiki under low concentration of arsenic, while the increase in arsenic was mainly concentrated in the cell fluid after treatment with high concentration of arsenic.

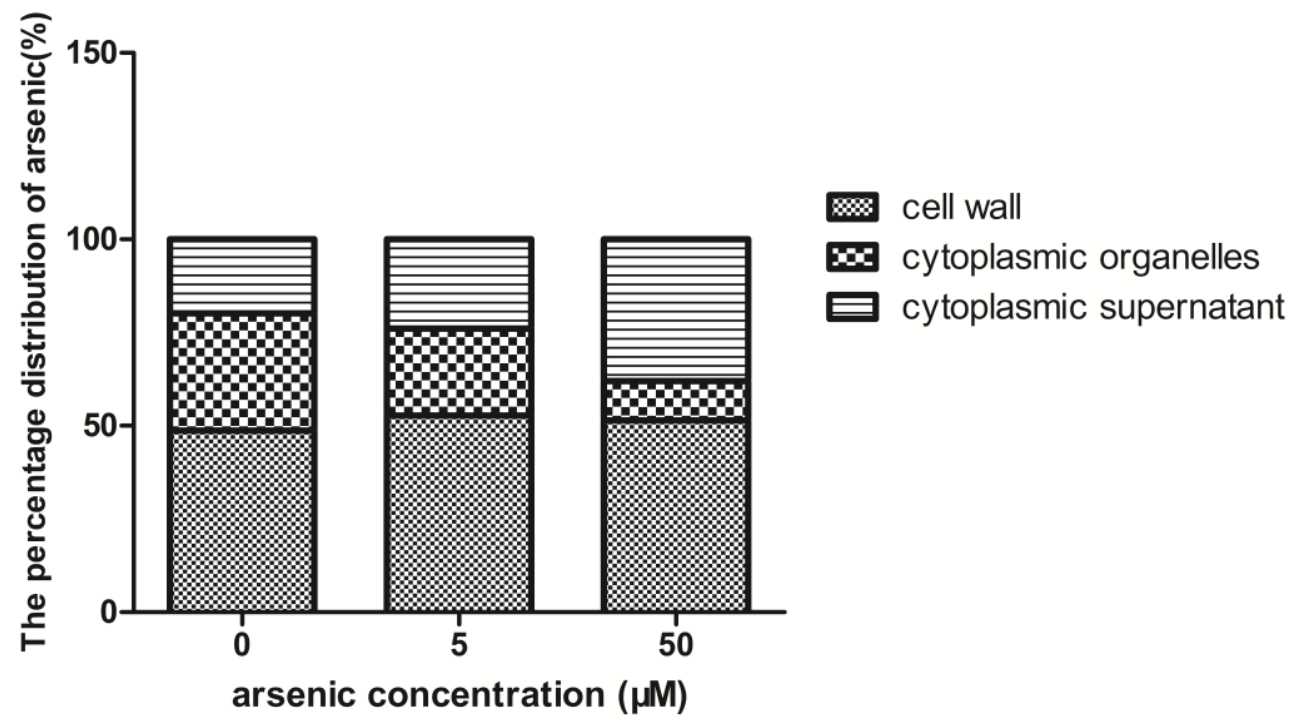

Figure 2. Subcellular distribution of arsenic in Sargassum fusiforme

\section{Results of arsenic speciation analysis}

The species of arsenic were determined with SA-10 Atomic Fluorescence Speciation Analyzer. The contents of arsenic species in each growth stage of the two hijiki are shown in Table 2. In this study, the extraction efficiency ranged from 75 to $90 \%$. Irrespective of the growth stage, inorganic arsenic (especially arsenate) was always the main form of arsenic present, accounting for about 77 to $88 \%$ of the total arsenic.

The contents of four arsenic species decreased in the order: AsV > AsIII > DMA > MMA. The organic arsenic content was negligible: the DMA and MMA contents were $1-4 \%$ and $1-3 \%$ of the total arsenic, respectively. 
Table 2. Contents of four arsenical species in different growth stages of the two Sargassum fusiforme varieties

\begin{tabular}{c|c|c|c|c|c}
\hline Growth stage & t-As & As (V) & As (III) & DMA & MMA \\
\hline Native & & & & & \\
Jan & $48.72 \pm 7.98$ & $30.06 \pm 2.10$ & $6.21 \pm 1.32$ & $0.68 \pm 0.05$ & $0.22 \pm 0.01$ \\
Feb & $56.98 \pm 17.97$ & $34.23 \pm 6.59$ & $7.2 \pm 0.48$ & $1.24 \pm 0.12$ & $0.34 \pm 0.07$ \\
Mar & $68.54 \pm 16.48$ & $42.46 \pm 10.13$ & $7.78 \pm 1.09$ & $0.49 \pm 0.10$ & $0.21 \pm 0.08$ \\
Apr & $72.29 \pm 22.17$ & $56.92 \pm 10.52$ & $6.25 \pm 0.74$ & $0.92 \pm 0.09$ & $0.26 \pm 0.09$ \\
May & $84.37 \pm 8.27$ & $67.63 \pm 8.43$ & $7.18 \pm 1.22$ & $1.18 \pm 0.14$ & $1.02 \pm 0.02$ \\
Korean & & & & & \\
Jan & $35.05 \pm 2.56$ & $24.75 \pm 2.40$ & $6.75 \pm 1.56$ & $1.04 \pm 0.06$ & $0.19 \pm 0.16$ \\
Feb & $38.31 \pm 4.72$ & $28.24 \pm 0.25$ & $7.47 \pm 0.45$ & $0.73 \pm 0.05$ & $0.32 \pm 0.07$ \\
Mar & $56.97 \pm 3.67$ & $34.24 \pm 9.35$ & $7.67 \pm 2.72$ & $1.66 \pm 0.08$ & $0.39 \pm 0.04$ \\
\hline
\end{tabular}

Native: native hijiki variety. Korean: Korean hijiki variety. t-As: total arsenic. As (V): arsenate. As (III): arsenite. DMA: dimethylarsinic acid. MMA: monomethylarsonic acid. Results expressed in $\mathrm{mg} / \mathrm{kg}$ dry weight and as mean of triplicate assays

\section{Kinetics of arsenic uptake}

The results showed that with increase in As concentration, arsenic absorption increased gradually, and the trivalent arsenic tended to be stable when the arsenic concentration reached $20 \mu \mathrm{mol} / \mathrm{L}$. The absorption of the pentavalent arsenic tended to be stable after the arsenic concentration reached $60 \mu \mathrm{mol} / \mathrm{L}$ (Figure 3). The kinetics of arsenic and arsenate were in accord with the Michaelis-Menten equation, with $\mathrm{R}^{2}$ values of 0.9744 and 0.9624 for arsenic and arsenate, respectively. The $\mathrm{V}_{\max }$ for arsenate uptake (1202 ng/g DW min) was about twice that of arsenic uptake (619 ng/DW min). The $\mathrm{K}_{\mathrm{m}}$ value of arsenate $(12.91 \mu \mathrm{mol} / \mathrm{L})$ was about three times that of $\operatorname{arsenic}(4.591 \mu \mathrm{mol} / \mathrm{L})$.

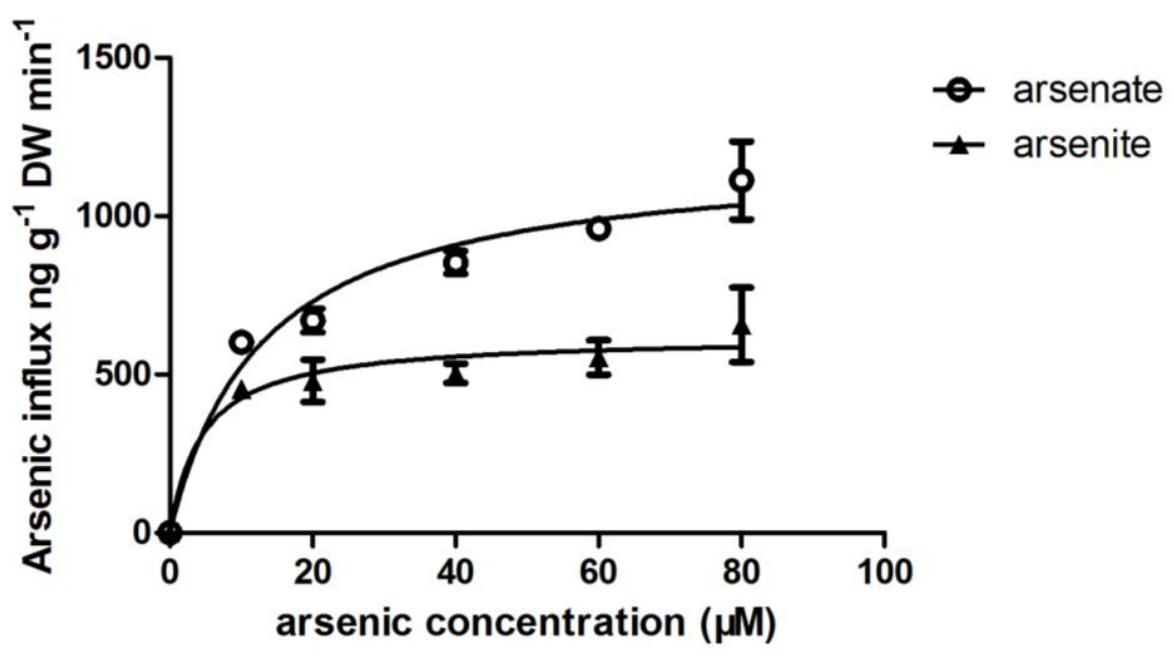

Figure 3. Concentration-dependent kinetics for arsenate (open circles) and arsenite (closed triangles) uptake in Sargassum fusiforme 


\section{Arsenic influx and efflux in hijiki}

After treatment with $50 \mu \mathrm{mol} / \mathrm{L}$ As for $1 \mathrm{~h}$, the contents of arsenic and arsenate in hijiki were 61.8 and $39.9 \mu \mathrm{g} / \mathrm{g}$ dry weight, respectively. The absorption of arsenic was significantly higher than that of arsenate, about 1.5 times higher. The absorption of arsenate was obviously inhibited by phosphorus, while arsenic was not inhibited by phosphorus. Although glycerol inhibited the absorption of arsenic, it had little effect on the absorption of arsenate (Figure 4). In the control group, the amount of arsenic in hijiki was slightly higher than that of arsenate. After CCCP, sodium vanadate and glycerol were added to the solution. Sodium vanadate significantly increased the efflux of arsenate, but it had no effect on the efflux of arsenic. Treatment with CCCP and glycerol inhibited the efflux of arsenic, but there was no significant difference between them, and they had little effect on the efflux of arsenate (Figure 5).

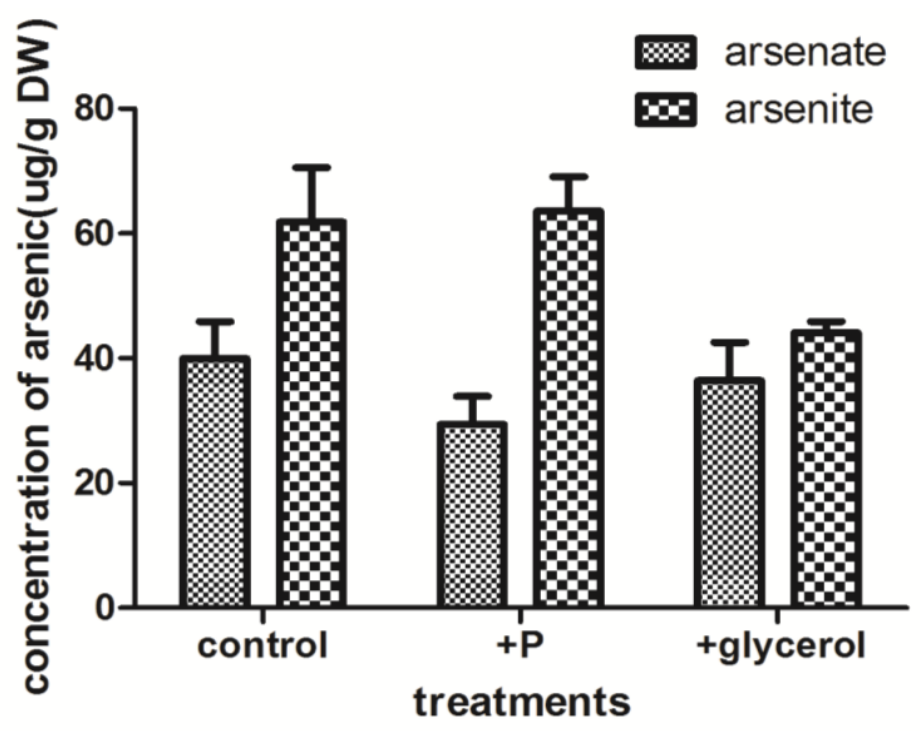

Figure 4. Influence of $P(100 \mu \mathrm{mol} / \mathrm{L})$ and glycerol $(20 \mathrm{mmol} / \mathrm{L})$ on the uptake of arsenate and arsenite

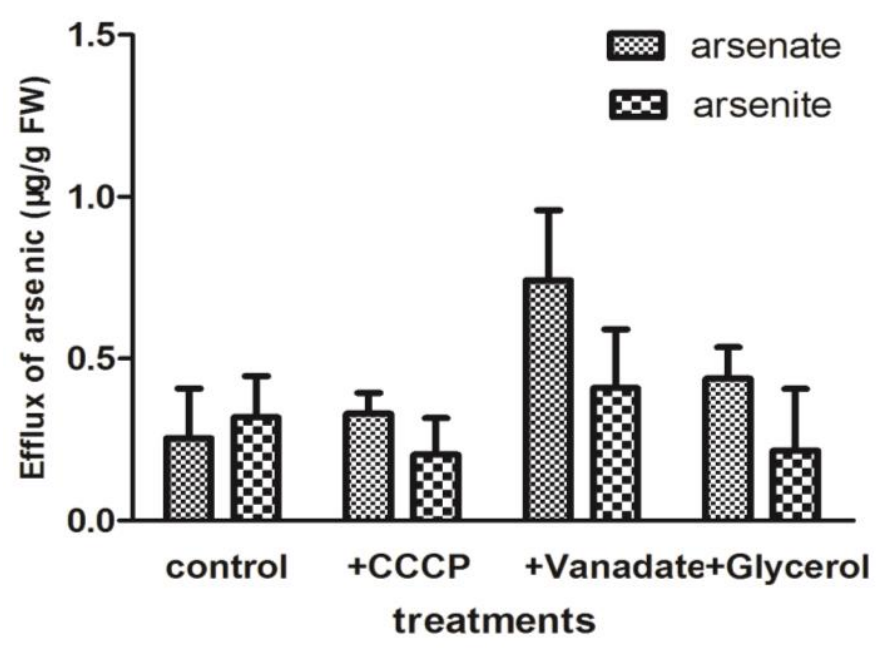

Figure 5. Effects of CCCP $(1 \mu \mathrm{mol} / \mathrm{L})$, sodium vanadate $(200 \mu \mathrm{mol} / \mathrm{L})$, and glycerol $(10 \mathrm{mmol} / \mathrm{L})$ on the efflux of arsenate and arsenite 


\section{Discussion}

Several studies have reported total and inorganic arsenic contents in seaweeds. A study on a wide variety of seaweeds found that the concentrations of total arsenic varied from 2.2 to $149 \mathrm{mg} / \mathrm{kg}$ dry weight, and that the total arsenic content was related to the type of seaweed, decreasing in the order: brown seaweed $>$ red seaweed $>$ green seaweed (Almela et al., 2002). The arsenic contents of hijiki were especially high (68.3 to $149 \mathrm{mg} / \mathrm{kg}$ dry weight), as had been reported in the literature, which indicated that it could attain $179 \mathrm{mg} / \mathrm{kg}$ dry weight (Almela et al., 2002, 2006; Rose et al., 2007; Hamano-Nagaoka et al., 2008; Yokoi et al., 2012). Thus, the contents detected in the present study were high, but were still low, when compared to values reported in other studies. In the organs, the levels decreased in the order: rhizoid > leaf > air sac > stem. Since rhizoid is an inedible part of hijiki, this result suggests that hijiki with more stem and leaves than air sac should be selected.

In this research, the total arsenic content of the native hijiki was always higher than that of the Korean hijiki. These results differ from those of Ichikawa (2006), in which the ranges of total arsenic concentrations in hijiki gathered from the shores in Japan, South Korea, and China were 41.7- 46.7, 65.6 - 79.8, and 36.0 - $48.6 \mathrm{mg} \mathrm{As} / \mathrm{kg}$, respectively. Besides, arsenic concentrations in hijiki grown in gulfs were higher in than those in hijiki grown in coastline of open sea. This may have been influenced by lower pollutant concentrations and increased circulatory flow in the coastline of open sea. However, the arsenic concentrations in hijiki increased with growth. In this study, we also detected the arsenic content in the seawater from where the hijiki planted. The results showed that the content of arsenic in seawater is very low (1-7 ug/L). So we think that the arsenic contents in hijiki were not consistent with that in the seawater. The high content of arsenic in hijiki is not caused by the amount of arsenic in seawater. This may indicate that the accumulation of high arsenic content in hijiki was not caused by the arsenic content of seawater but by the high ability of arsenic absorption of hijiki.

Marine organisms have been examined extensively for arsenic species in recent decades. Marine animals contain mainly arsenobetaine, and nearly no MMA, DMA, TMA, AsCho, or TMAs (Kohlmeyer et al., 2003). Arsenosugars and arsenobetaine have been found in bivalves (Lai et al., 2001). In fish, there is hardly any inorganic arsenic or arsenosugars but trimethylarsoniopropionate has been detected in fish muscle (Francesconi et al., 2000). Many scholars have reported that the main arsenic species in hijiki is arsenate, and the level can reach approximately $65 \%$ of the total arsenic (Kohlmeyer et al., 2003; Raab et al., 2005; Hanaoka et al., 2006; Ichikawa et al., 2006; Hamano-Nagaoka et al., 2008). Park et al. (2019) also found that arsenate was the predominant arsenic species in hijiki, accounting for approximately $60 \%$ of the total arsenic content. These are similar to the results of this study, although the proportion of arsenate was greater (77 to $88 \%$ ): the proportion of arsenite was between 10 to $20 \%$. The concentration of organic arsenic was low, the DMA content being just 1 to $4 \%$ of the total arsenic present, and the MMA content was much smaller. These data are in agreement with the findings of Ichikawa et al. (2006).

In this study, after treatment with $50 \mu \mathrm{mol} / \mathrm{L}$ arsenic and arsenate for $1 \mathrm{~h}$, the content of arsenate in hijiki was higher than that of arsenic. Compared with arsenic, arsenate had higher Vmax and smaller $\mathrm{K}_{\mathrm{m}}$ value in hijiki, and the absorption of arsenate was higher than that of arsenic. Compared with other aquatic plants such as Azolla caroliniana, Azolla filiculoides and Ceratophyllum demersum, hijiki has higher degree of absorption and lower $\mathrm{K}_{\mathrm{m}}$ value for arsenate (Xue et al., 2012). This also shows that hijiki has a 
transport system with high affinity for arsenate. In the study of Xue et al. (2012), the $\mathrm{V}_{\max }$ values of arsenic and arsenate in $C$. demersum were 214 and $128 \mathrm{nmol} / \mathrm{L} / \mathrm{g} \mathrm{DW}$ min, respectively, which were lower than that in hijiki. The $\mathrm{K}_{\mathrm{m}}$ values of arsenic and arsenate in $C$. demersum were 18 and $120 \mu \mathrm{mol} / \mathrm{L}$, respectively, which were about 1.5 and 25 times, respectively higher than that of hijiki. Compared with $C$. demersum, hijiki had higher affinity for arsenic and arsenate.

Phosphorus and arsenic are homologous elements. The chemical properties of phosphate and arsenate are similar. Therefore, in higher plants, arsenate enters plants by sharing the same uptake and transport protein with phosphate (Asher and Reay, 1979). The absorption process is mainly completed by the coordinated transport of arsenate or phosphate $\left(\mathrm{H}_{2} \mathrm{PO}_{4}{ }^{-} / \mathrm{H}_{2} \mathrm{AsO}_{4}{ }^{-}\right)$and protons. The results of this study also showed that the absorption of arsenic in hijiki was inhibited by $\mathrm{P}$ in the environment, indicating that As and $\mathrm{P}$ share the same absorption channel in hijiki. Some plants can adjust the expression of phosphate transporters to reduce the absorption of arsenate, thereby adapting to the high concentration of arsenic pollution in soil (Meharg and Hartley Whitaker, 2002).

Unlike arsenate, the absorption of arsenic is not affected by phosphate. Arsenic has been shown to be able to enter the cell through water channel proteins in many plants (Meharg and Jardine, 2003; Zhao et al., 2009). Xue et al. (2012) found that the absorption of arsenate by $C$. demersum was significantly inhibited by $\mathrm{P}$ $\left(\mathrm{K}_{2} \mathrm{HPO}_{4} \cdot 3 \mathrm{H}_{2} \mathrm{O}\right)$ in solution, but was not inhibited by glycerol and $\mathrm{Sb}$ $\left(\mathrm{C}_{4} \mathrm{H}_{4} \mathrm{KO}_{7} \mathrm{Sb} \cdot 1 / 2 \mathrm{H}_{2} \mathrm{O}\right)$ in solution, while the absorption of arsenic was the opposite. This also shows that the uptake of arsenate in $C$. demersum shares the same transport protein with phosphate, and arsenic can enter the cells of $C$. demersum through water channels. In this study, it was found that the absorption and efflux of arsenic in hijiki were inhibited by glycerol, which is consistent with the previous results for Saccharomyces cerevisiae and rice (Wysocki et al., 2001; Meharg and Jardine, 2003). It can also be concluded that, like other plants, arsenate is mainly transported in and out of cells by active transport, while arsenic is mainly transported in and out of cells by passive transport.

\section{Conclusion}

Overall, the results support the view that hijiki has a high concentration of inorganic arsenic. The dominant arsenic species in hijiki was found to be arsenate. To guarantee public food safety, besides warning people not to eat hijiki, future research into the selection of a hijiki variety which accumulates less arsenic, such as the Korean hijiki studied here, is recommended. Moreover, it is important to select a variety which has more leaves and stem instead of varieties with more air sacs. Harvesting hijiki a little earlier may also be a way of ensuring decreased accumulation of arsenic.

Research on the absorption and metabolism of arsenic can help in understanding of the mechanism of arsenic uptake and transport. This study lays the foundation for As control technology in hijiki, and is important for the safety of edible hijiki, and the development of hijiki industry. But what does the mechanism of arsenic absorption in hijiki? How to reduce the arsenic absorption of hijiki? These are all issues that need further study in the future. 
Acknowledgements. This research was financially supported by the Natural Science Foundation of Zhejiang Province (LY15C020003), the 'Five-twelfth' National Science and Technology Support Program (No. 2012BAK17B03), and Natural Science Foundation of China (31101133).

\section{REFERENCES}

[1] Agency for Toxic Substances and Disease Registry. (2018): Public health statement for arsenic.

[2] Almela, C., Algora, S., Benito, V., Clemente, M. J., Devesa, V., Su'ner, M. A., Vélez, D., Montoro, R. (2002): Heavy metals, total arsenic and inorganic arsenic contents of algae food products. - Journal of Agricultural and Food Chemistry 50(4): 918-923.

[3] Almela, C., Laparra, J. M., Vélez, D., Barberá, R., Farré, R., Montoro, R. (2005): Arsenosugars in Raw and Cooked Edible Seaweed: Characterization and Bioaccessibility. - Journal of Agricutural and Food Chemistry 53(18): 7344-7351.

[4] Almela, C., Clemente, M. J., Ve'lez, D., Montoro, R. (2006): Total arsenic, inorganic arsenic, lead and cadmium contents in edible seaweed sold in Spain. - Food and Chemical Toxicology 44(11): 1901-1908.

[5] Asher, C. J., Reay, P. F. (1979): Arsenic uptake by barley seedlings. - Functional Plant Biology 6(4): 459-466.

[6] Carey, A. M., Lombi, E., Donner, E., de Jonge, M. D., Punshon, T., Jackson, B. P., Guerinot, M. L., Price, A. H., Meharg, A. A. (2012): A review of recent developments in the speciation and location of arsenic and selenium in rice grain. - Analytical and Bioanalytical Chemistry 402(10): 3275-3286.

[7] Francesconi, K. A., Khokiattiwong, S., Goessler, W., Pedersen, S. N., Pavkov, M. (2000): A new arsenobetaine from marine organisms identified by liquid chromatography-mass spectrometry. - Chemical Communications 12: 1083-1084.

[8] García Salgado, S., Quijano Nieto, M. A., Bonilla Simón, M. M. (2008): Assessment of total arsenic and arsenic species stability in alga samples and their aqueous extracts. Talanta 75: 897-903.

[9] Hamano-Nagaoka, M., Hanaoka, K., Usui, M., Nishimura, T., Maitani, T. (2008): Nitric Acid-based Partial-digestion Method for Selective Determination of Inorganic Arsenic in Hijiki and Application to Soaked Hijiki. - Journal of the Food Hygienic Society of Japan 49(2): 88-94.

[10] Han, C., Cao, X., Yu, J., Wang, X. R., Shen, Y. (2009): Determination of Trace Elements in Sargassum Fusiforme by Microwave Digestion with ICP-MS. - Chinese Journal of Spectroscopy Laboratory 26(3): 480-483.

[11] Hanaoka, K., Yosida, K., Tamano, M., Kuroiwa, T., Kaise, T., Maeda, S. (2006): Arsenic in the prepared edible brown alga hijiki, Hizikia fusiforme. - Applied Organometallic Chemistry 15: 561-565.

[12] Ichikawa, S., Kamoshida, M., Hanaoka, K., Hamano, M., Maitani, T., Kaise, T. (2006): Decrease of arsenic in edible brown algae Hijikia fusiforme by the cooking process. Applied Organometallic Chemistry 20: 585-590.

[13] Ichikawa, S., Nozawa, S., Hanaoka, K., Kaise, T. (2010): Ingestion and excretion of arsenic compounds present in edible brown algae,Hijikia fusiforme, by mice. - Food and Chemical Toxicology 48: 465-469.

[14] Kohlmeyer, U., Jantzen, E., Kuballa, J., Jakubik, S. (2003): Benefits of high resolution IC-ICP-MS for the routine analysis of inorganic and organic arsenic species in food products of marine and terrestrial origin. - Analytical and Bioanalytical Chemistry 377: 6-13.

[15] Lai, V. W. M., Cullen, W. R., Ray, S. (2001): Arsenic speciation in sea scallop gonads. Applied Organometallic Chemistry 15(6): 533-538. 
[16] Meharg, A. A., Hartley-Whitaker, J. (2002): Arsenic uptake and metabolism in arsenic resistant and nonresistant plant species. - New Phytologist 154(1): 29-43.

[17] Meharg, A. A., Jardine, L. (2003): Arsenite transport into paddy rice (Oryza sativa) roots. - New Phytologist 157: 39-44.

[18] National Food Safety standard (2003): Determination of Total Arsenic and Abio-Arsenic In Foods. - GB/T 5009.11, 2003.

[19] Nogueira, R., Melo, E. A., Figueiredo, J. L., Santosa, J. J., Nascimento Netoa, A. P. (2018): Arsenic Speciation in Fish and Rice by HPLC-ICP-MS Using Salt Gradient Elution. - Journal of Brazilian Chemical Society 29(8): 1593-1600.

[20] Panuccio, M. R., Logoteta, B., Beone, G. M., Cagnin, M., Cacco, G. (2012): Arsenic uptake and speciation and the effects of phosphate nutrition in hydroponically grown kikuyu grass (Pennisetum clandestinum Hochst). - Environental Science and Pollution Research 19: 3046-3053.

[21] Park, G. Y., Kang, D. E., Davaatseren, M. S. C., Kang, G. J., Chung, M. S. (2019): Reduction of total, organic, and inorganic arsenic content in Hizikia fusiforme (Hijiki). Food Science and Biotechnology 28(2): 615-622.

[22] Quaghebeur, M., Rengel, Z. (2005): Arsenic Speciation Governs Arsenic Uptake and Transport in Terrestrial Plants. - Microchimica Acta 151: 141-152.

[23] Raab, A., Fecher, P., Feldmann, J. (2005): Determination of Arsenic in Algae- Results of an Interlaboratory Trial: Determination of Arsenic Species in the Water-Soluble Fraction. - Microchimica Acta 151: 153-166.

[24] Raab, A., Paul, W., Meharg, A. A., Feldmann, J. (2007): Uptake and translocation of inorganic and methylated arsenic species by plants. - Environmental Chemistry 4(3): 197-203.

[25] Rose, M., Lewis, J., Langford, N., Baxter, M., Origgi, S., Barber, M., Origgi, S., Barber, M., MacBain, H., Thomas, K. (2007): Arsenic in seaweed-Forms, concentration and dietary exposure. - Food and Chemical Toxicology 45(7): 1263-1267.

[26] Rosen, B. P. (2002): Biochemistry of arsenic detoxification. - FEBS Letters 529: 86-92.

[27] Wang, L., Gao, S., Yin, X., Yu, X., Luan, L. (2019): Arsenic accumulation, distribution and source analysis of rice in a typical growing area in north China. - Ecotoxicology and Environmental Safety 167: 429-434.

[28] Wondimu, T., Ueno, A., Kanamaru, I., Yamaguchi, Y., McCrindle, R., Hanaoka, K. (2007): Temperature-dependent extraction of trace elements in edible brown alga hijiki, Hizikia fusiforme. - Food Chemistry 104: 542-550.

[29] Wysocki, R., Chery, C. C., Wawrzycka, D., Van Hulle, M., Cornelis, R., Thevelein, J. M., Tamas, M. J. (2001): The glycerol channel Fps1p mediates the uptake of arsenite and antimonite in Saccharomyces cerevisiae. - Molecular Microbiology 40: 1391-1401.

[30] Xu, X. Y., McGrath, S. P., Zhao, F. J. (2007): Rapid reduction of arsenate in the medium mediated by plant roots. - New Phytol 176: 590-599.

[31] Xue, P., Yan, C., Sun, G., Luo, Z. (2012): Arsenic accumulation and speciation in the submerged macrophyte Ceratophyllum demersum L. - Environmental Science and Pollution Research 19: 3969-3976.

[32] Yang, S. H., Park, J. S., Cho, M. J., Choi, H. (2016): Risk analysis of inorganic arsenic in foods. - Journal of Food Hygiene Safety 31(4): 227-249.

[33] Yokoi, K., Konomi, A. (2012): Toxicity of so-called edible hijiki seaweed (Sargassum fusiforme) containing inorganic arsenic. - Regulatory Toxicology and Pharmacology 63: 291-297.

[34] Zhao, F. J., Ma, J. F., Meharg, A. A., McGrath, S. P. (2009): Arsenic uptake and metabolism in plants. - New Phytologist 181: 777-794.

[35] Zheng, T., Liu, C. C., Yang, J. Y., Liu, Q. G. (2013): Hijiki Seaweed (Hizikia fusiformis): Nutritional Value, Safety Concern and Arsenic Removal Method. Advanced Materials Research 638(1): 1247-1252. 